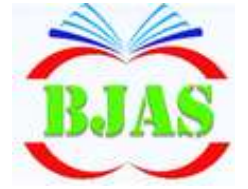

ISSN $1814-5868$
Available online at http://bjas.bajas.edu.iq https://doi.org/10.37077/25200860.2021.34.2.19 College of Agriculture, University of Basrah

Basrah J. Agric. Sci., 34(2), 253-266, 2021

\section{Basrah Journal of Agricultural Sciences \\ $, \ldots, \ldots, \ldots, \ldots, \ldots$}

E-ISSN: 2520-0860

\title{
Pedogenical Distribution of some Micronutrients in Prevailing Sub Great Soil Group in Iraq
}

Ali H. I. Al-Bayati ${ }^{* 1}$, AbdulKarem A. M. Alalwany ${ }^{2}$ \& Mohammed Abdal-Mnam Hassan.1

\author{
${ }^{1}$ State Company for Foodstuff Trading, Ministry of Trade, Iraq \\ ${ }^{2}$ Department of Plant Protection, College of Agriculture, University of Basrah, Iraq \\ *Correspondence, author email: albayati1961@yahoo.com; ds.dr.abdalkareem@uoanbar.edu.iq \\ ag.mohammed.abdal-mnam@uoanbar.edu.iq
}

Received 17 ${ }^{\text {th }}$ February 2020; Accepted 28 ${ }^{\text {th }}$ November 2021; Available online $1^{\text {th }}$ December 2021

\begin{abstract}
The study included the analysis of (341) samples from eight pedons cover most of the prevailing sub great soil groups in Iraq, which are (Typic Torrifluvents, Typic Torrients, Typic Gypsiorthids, Typic Calciorthids, Aquollic Salorthids, Typic Chromoxerects, Typic Xerrochrepts and Typic Calcixerects) to study the pedogenetic distribution of total and bioavailable content of the manganese, zinc, copper, and iron also its relationship with some soil properties. Results showed significant differences between the studied regions of total content of microelements, the bioavailability content also showed a significant deference between the studied regions. The physical and chemical soil properties clearly affected on their content of micronutrient and $77 \%$ of the studied samples were below the critical limit for zinc, but $65 \%$ of the studied samples were under the critical limit for iron. This refers to the response of the cultivated crops in such sub great soil groups to the addition of $\mathrm{Zn}$ and Fe fertilizers, also pedogenetic distribution of the content of these microelements showed a decrease with depth and compatible with the distribution of each of the separated clay and organic matter and decrease with the increase in the soil content of calcium carbonate.
\end{abstract}

Keywords: Micronutrients; Iraqi soil; Soil properties.

\section{Introduction}

Micronutrients pedological distribution in the soil studies are considered tropics of interest to researchers in the field of soil science and plant, because of its pedological and edaphological importance, as it's considered an important tool to determine the soil fertility level (Al-Agidi,1986). The correlated micronutrients implied that they were affected by similar factors. Soil $\mathrm{pH}$ correlated positively with $\mathrm{B}, \mathrm{Fe}$, and $\mathrm{Mn}$ and negatively with $\mathrm{Cu}$ and $\mathrm{Zn}$, hence probably influencing their availability. Therefore, the need for sustaining micronutrient at sufficient levels is crucial. Management interventions may include moderating soil $\mathrm{pH}$ by reducing acidity through liming in the higher elevations and incorporation of organic matter in the lowlands (Amos et al, 2016). Donisa et al. (2003) when they studied the pedological distribution for eleven elements $(\mathrm{Al}, \mathrm{Fe}, \mathrm{Ca}$, 


\section{Al-Bayati et al. / Basrah J. Agric. Sci., 34(2), 253-266, 2021}

$\mathrm{Mg}, \mathrm{K}, \mathrm{Mn}$ and the trace elements $\mathrm{Cu}, \mathrm{Pb}, \mathrm{Zn}$, $\mathrm{Cd}$, and $\mathrm{Cr}$ ) in the Andosols, Podzols and Cambisols in Romania, noted a significant differences between soils types according to their availability content, with a linear drop in the soil content for all studied elements with depth.

Donald et al. (1952) noted that there is a general decrease in the availability of $\mathrm{Zn}$ and $\mathrm{Cu}$ followed with Mo as well as Fe and Mn, with a significant decrease in the soil content of these elements availability with depth in seven Australian soil orders, due to the active installation of the soil for these nutrients due to increased soil content of calcium carbonate. The availability of micronutrients in soil is dependent on the parent material, pedogenic processes and soil management techniques that may promote in some cases a reduction of cationic micronutrient contents (Pegoraro et al., 2006).

Sharma et al. (2011) showed the total Mn content in arid zones of Punjab- north western of India was ranged from 241 and $517 \mathrm{mg} \mathrm{Kg}^{-}$ 1, while the bioavailable Mn content was ranged from 1.40 and $4.52 \mathrm{mg} \mathrm{Kg}^{-1}$ and the two forms did not exhibit any consistent pattern of distribution. Mn content was higher in the fine textured soils as compared to the coarse textured soils. The bioavailable $\mathrm{Mn}$ was increased with increase the soil organic carbon content. However, both these fractions decreased with an increase in calcium carbonate and $\mathrm{pH}$.

Chandragouda et al. (2017) results indicated higher concentration of DTPA extractable micronutrients namely, $\mathrm{Fe}, \mathrm{Cu}$ and $\mathrm{Zn}$ in surface than in sub surface soils was observed all along the water course. However fertility status of soils along the water course was low with respect to both available $\mathrm{N}$ and $\mathrm{P}$, medium with respect to available $\mathrm{K}, \mathrm{S}, \mathrm{Fe}$ and $\mathrm{Zn}$ while high with respect to available $\mathrm{Cu}$ and Mn. Chahal et al. (2014) investigated for different forms of $\mathrm{Zn}$ content, including the total and bioavailable in the semi-arid-zone soils in Punjab, northwest India. The soils content of this element was higher in finetextured Alfisols and Inceptisols than in coarse-textured Entisols order soils. In general, the higher content was observed in the surface horizon Kingsley et al. (2019) showed that the soils along a hill slope of Ekpri Ibami in Nigeria, are characterized by sandy loam texture, with strongly acidic reaction and low organic forms of $\mathrm{Zn}$ exhibited any consistent pattern of distribution. Organic matter and particle size fractions (clay and silt) had a strong influence on the distribution of different forms of $\mathrm{Zn}$. Shukla et al. (2015) explained the micronutrient deficiency is major constraints in crop production as well as crop quality. The level of micronutrients in soils is determined by geologic substrate and subsequent geochemical and pedogenic processes. However, their availability depends on soil $\mathrm{pH}$, organic carbon content and absorptive surface like $\mathrm{CaCO}_{3}$ and clay content and other physical, chemical and biological conditions of the rhizosphere. The analysis of 5673 soil samples collected across the Haryana state showed a wide variability in status of available micronutrient deficiency in soils.

Bhaskar et al. (2017) studied soil series in rice-growing soils of Majuli island, to understanding the pedogenic influence on distribution and content of total and bioavailable ( $\mathrm{Fe}, \mathrm{Mn}, \mathrm{Cu}$ and $\mathrm{Zn}$ ) and their enrichment levels. The correlation analysis showed that these elements were closely linked with soil texture, organic carbon, cation exchange capacity and $\mathrm{pH}$ levels. 


\section{Al-Bayati et al. / Basrah J. Agric. Sci., 34(2), 253-266, 2021}

The multiple regressions and cluster analysis was employed to identify the effect of river fed deposits on distribution pattern and lithological enrichment of metals.

da Silva et al. (2019) showed that the soils which is cultivated with sugarcane in the states of Paraíba and Pernambuco posed available and reserve contents of $\mathrm{Mn}, \mathrm{Zn}$, and content. $\mathrm{Cu}$ related to the parent materials and soil textural classes. The Fe content was high $\left(5 \mathrm{mg} \cdot \mathrm{Kg}^{-1}\right)$ in all the studied positions, copper was rated medium (0.2-2.0 mg. $\left.\mathrm{Kg}^{-1}\right)$, zinc was rated low to medium (0.8-2.0 mg. $\left.\mathrm{Kg}^{-1}\right)$, manganese was rated medium $\left(1.1-5.0 \mathrm{mg} . \mathrm{Kg}^{-}\right.$ ${ }^{1}$ ) in all positions. The soils will not require supplementary application of $\mathrm{Fe}$ fertilizer since they are above critical limits of arable production, but a complementary supply of copper, zinc and manganese fertilizers are strongly recommended to enhancing the soil fertility status of the area.

Shukla et al. (2020) studied the spatial distribution pattern of available micronutrients $\mathrm{Zn}, \mathrm{B}, \mathrm{Fe}, \mathrm{Mn}$ and $\mathrm{Cu}$, also sulphur $\mathrm{S}$ and some soil properties in the intensively cultivated Indo-Gangetic Plain (IGP) of India to delineate the soil management zones for efficient management of soil nutrients. Geostatistical analysis resulted in varied distribution pattern of studied soil parameters with moderate to strong spatial dependence. The extent (\% area) of nutrient deficiencies in IGP followed the order: $\mathrm{S}>\mathrm{Zn}>\mathrm{B}>\mathrm{Mn}>\mathrm{Cu}>\mathrm{Fe}$.

Therefore, present investigation was undertaken to generate information concerning pedological distribution of some microelements in some great soil groups in Iraq.

\section{Materials \& Methods}

\section{Selection of study sites}

According to the supremacy of the soil's order in Iraq, eight locations were chosen for obtaining samples, as shown in the fig. (1), included the regions Abu Ghraib and Diyala $\mathrm{P} 1$ and P2 as Entisols soils within the great group Torriorthents and Torrifluvents, respectively, Rabia, Ramadi and Delmj marsh P3, P4 and P5 as Aridisols order within the great groups Gypsiorthids, Calciorthids and Salorthids respectively, the Sindi region P6 representative of Vertisols order and Bashiqah P7 representative of Inceptisols order, finally Aqre P8 within Mollisols order.

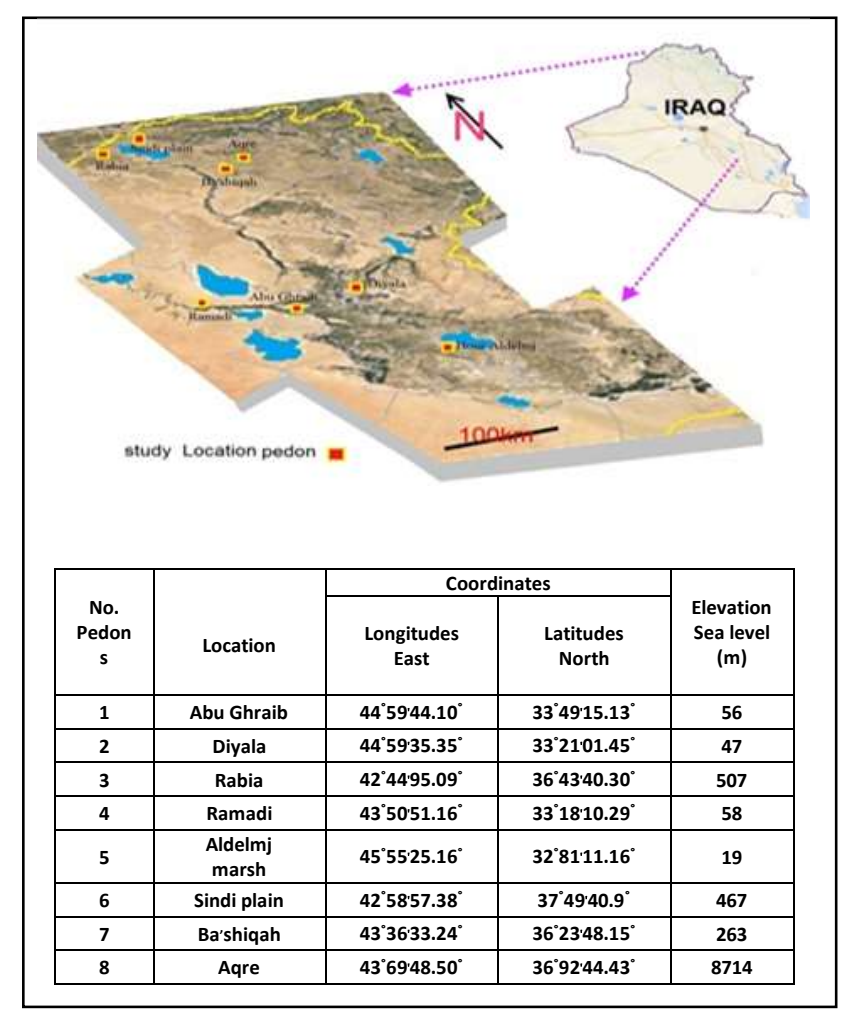

Fig. (1): Locations of study

\section{Laboratory analysis}

After positioning every region, every site was morphologically description according to Soil Survey Division Staff (2017), and samples representative of each diagnostic horizon were obtained, and based on the 


\section{Al-Bayati et al. / Basrah J. Agric. Sci., 34(2), 253-266, 2021}

results of its analysis, they were classified according to the American classification (Soil Survey Staff, 2006).

At each test site, samples were obtained at the same depths for ten sites randomly distributed around each pedon, from which soil samples were obtained by auger, and some physical and chemical properties were estimated in addition to the soil content of the total and bioavailable micro-elements (Fe, $\mathrm{Zn}, \mathrm{Mn}$ and $\mathrm{Cu}$ ). The total studied soil samples reached 341 .

The samples were air dried, ground by wooden hammer and passed through a $2 \mathrm{~mm}$ sieve, then preserved in plastic containers, for analysis of some physical and chemical properties and micronutrient contents. Each sample was tested for the electrical conductivity and soil reaction were estimated in the saturated paste using electrical conductivity and $\mathrm{pH}$ meter devices. Cat ions exchangeable capacity (CEC) was determined by distillation method as described by Richards (1954), The quantity of organic carbon in the soil was estimated by using Walkey-Black method that was mentioned in Jackson (1958), Soil texture was estimated using hydrometer (Day, 1965). Each sample was tested for the presence of carbonates and gypsum according to the methods in Page et al. (1982).

Total soil content of iron and copper were estimated by methods mentioned in Jackson (1958), whereas the total soil content of Zinc by the method of Tucker \& Kurtz (1955), total manganese soil content was estimated using the method described by Hesse (1971).

The soil samples content from available micronutrients were analyzed for $(\mathrm{Zn}, \mathrm{Fe}, \mathrm{Mn}$, and $\mathrm{Cu}$ ) by adopting standard procedures for soil analysis. Analysis of $\mathrm{Zn}, \mathrm{Fe} \mathrm{Mn}$, and $\mathrm{Cu}$ was performed using Diethylene Triamine Penta Acetic Acid (0.005 DTPA+0.1 M Triethanol amine and $0.01 \mathrm{M} \mathrm{Ca} \mathrm{Cl} 2$ solution buffer) as outlined by Lindsay \& Norwell (1978).

The application of atomic absorption to studies of trace elements in soils, plants, and animals provided large amounts of information on the function and distribution of trace elements in the environment. There has been increased awareness of and research on interactions, both among trace elements, and between trace elements and other dietary constituents by Ross et al. (1991).

\section{Statistical analysis}

The correlations of soil total and DTPA extractable heavy metal contents with physical and chemical characteristics were tested using Pearson's correlation and multiple regression analysis. The cluster analysis was made to test similarities with the average linkage method (within group) using PASW-18 version.

\section{Results \& Discussion}

\section{Some physical and chemical properties for studied soils.}

Table (1) showed that soil content of sand ranges between $15 \mathrm{gmKg}^{-1}$ soil at $\mathrm{Ck} 2$ in Ramadi site and $480 \mathrm{gmKg}^{-1}$ soil at horizon Cy1 Rabia site, with a variation in the sand content from location to another and within each site vertically, however soil content from silt ranges between $310 \mathrm{gmKg}^{-1}$ soil at $\mathrm{Cy} 2$ horizon in Rabia site and $700 \mathrm{gmKg}^{-1}$ soil at horizon Ay in Aqra site, with supremacy for this particle in comparison to sand and clay at all selected locations. The clay fraction results which was observed in the Tab. 1 showed that its value ranges from $90 \mathrm{gmKg}^{-1}$ soil at horizon C3 in Rabia region compared with the highest content which was recorded at horizons $A_{k}$ and Cw2 in Sindi region and the horizon Bk in Bashiqah reached 580 gm. $\mathrm{Kg}^{-1}$ soil. 
Al-Bayati et al. / Basrah J. Agric. Sci., 34(2), 253-266, 2021

Table (1): Some physical and chemical properties for studied soils.

\begin{tabular}{|c|c|c|c|c|c|c|c|c|c|c|c|c|c|}
\hline \multirow{2}{*}{ Classification to family level } & \multirow{2}{*}{$\underset{\Xi}{\Xi}$} & \multirow{2}{*}{ 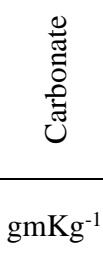 } & \multirow{2}{*}{ 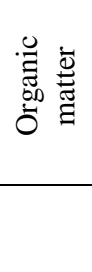 } & \multirow{2}{*}{ 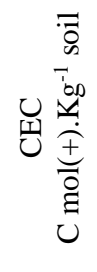 } & \multirow{2}{*}{$\mathrm{pH}$} & \multirow{2}{*}{$\begin{array}{c}\mathrm{ECe} \\
\mathrm{dSm}^{-1}\end{array}$} & \multirow{2}{*}{ 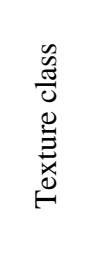 } & \multicolumn{3}{|c|}{ Particle size distribution } & \multirow{2}{*}{$\begin{array}{l}\text { Depth } \\
\text { (cm) }\end{array}$} & \multirow{2}{*}{ 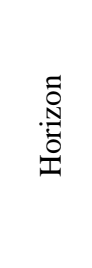 } & \multirow{2}{*}{ 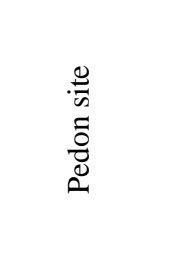 } \\
\hline & & & & & & & & \multicolumn{3}{|c|}{$\mathrm{gmKg}^{-1}$} & & & \\
\hline \multirow{5}{*}{$\begin{array}{c}\text { Fine loamy; mixed; (Calcareaus); } \\
\text { Alkalinre; Hyper thermic; Typic } \\
\text { Torrifluvents }\end{array}$} & 15 & 257 & 8 & 22.1 & 7.7 & 2.0 & SiL & 200 & 580 & 220 & $0-17$ & Ap & \multirow{5}{*}{$\begin{array}{l}\text { Abu Ghraib } \\
\text { P1 }\end{array}$} \\
\hline & 13 & 353 & 6 & 27.6 & 7.7 & 3.8 & $\mathrm{SiC}$ & 440 & 450 & 110 & $17-42$ & Ck1 & \\
\hline & 15 & 245 & 5 & 20.9 & 7.6 & 4.0 & $\mathrm{SiC}$ & 410 & 490 & 100 & $42-72$ & Ck2 & \\
\hline & 8 & 226 & 4 & 21.6 & 7.6 & 5.2 & $\mathrm{SiL}$ & 190 & 560 & 250 & $72-100$ & $\mathrm{C} 3$ & \\
\hline & 10 & 237 & Nil & 19.3 & 7.8 & 5.7 & $\mathrm{SiL}$ & 150 & 570 & 280 & $100-140$ & $\mathrm{C} 4$ & \\
\hline \multirow{4}{*}{$\begin{array}{c}\text { Fine loamy; mixed; (Calcareaus); } \\
\text { Alkalinre; Hyper thermic; Typic } \\
\text { Torrients }\end{array}$} & 10 & 330 & 8 & 16.1 & 7.7 & 4.6 & $\mathrm{SiC}$ & 400 & 510 & 90 & $0-20$ & Ap & \multirow{4}{*}{$\begin{array}{c}\text { Diyala } \\
\text { P2 }\end{array}$} \\
\hline & 11 & 335 & 3 & 18.5 & 7.7 & 4.0 & $\mathrm{SiC}$ & 460 & 500 & 40 & $20-40$ & Ck1 & \\
\hline & 11 & 342 & 4 & 16.7 & 7.8 & 5.1 & $\mathrm{SiC}$ & 490 & 480 & 30 & $40-60$ & $\mathrm{Ck} 2$ & \\
\hline & 28 & 329 & 2 & 15.1 & 8.0 & 9.8 & $\mathrm{SiC}$ & 510 & 460 & 30 & $60-140$ & $\mathrm{C} 3$ & \\
\hline \multirow{4}{*}{$\begin{array}{l}\text { Fine loamy; Gypsum; Alkalinre; Hyper } \\
\text { thermic; Typic Gypsiorthids }\end{array}$} & 482 & 53 & 5 & 6.8 & 7.7 & 3.3 & $\mathrm{~L}$ & 190 & 490 & 320 & $0-20$ & $\mathrm{~A}$ & \multirow{4}{*}{$\begin{array}{c}\text { Rabia } \\
\text { P3 }\end{array}$} \\
\hline & 600 & 20 & 3 & 6.2 & 7.7 & 4.0 & $\mathrm{~L}$ & 150 & 460 & 390 & $20-50$ & By & \\
\hline & 567 & 12 & 1 & 5.6 & 7.7 & 3.5 & $\mathrm{~L}$ & 200 & 320 & 480 & $50-80$ & Cy1 & \\
\hline & 551 & 15 & Nil & 7.4 & 7.6 & 3.5 & $\mathrm{~L}$ & 250 & 310 & 440 & $80-120$ & $\mathrm{Cy} 2$ & \\
\hline \multirow{4}{*}{$\begin{array}{c}\text { Fine silty; mixed; (Calcareaus); } \\
\text { Alkalinre; Hyper thermic; Typic } \\
\text { Calciorthids }\end{array}$} & 12 & 255 & 15 & 22.4 & 7.7 & 0.7 & $\mathrm{SiL}$ & 260 & 675 & 65 & $0-30$ & $\mathrm{~A}$ & \multirow{4}{*}{$\begin{array}{c}\text { Ramadi } \\
\text { P4 }\end{array}$} \\
\hline & 8 & 333 & 5 & 20.8 & 7.7 & 1.8 & $\widehat{\mathrm{SiCL}}$ & 340 & 605 & 55 & $30-70$ & $\mathrm{Bk}$ & \\
\hline & 10 & 330 & 3 & 22.6 & 7.5 & 3.7 & $\mathrm{SiCL}$ & 370 & 615 & 25 & $70-90$ & Ck1 & \\
\hline & 3 & 264 & 2 & 21.2 & 7.5 & 5.1 & SiCL & 360 & 625 & 15 & $90-150$ & $\mathrm{Ck} 2$ & \\
\hline \multirow{4}{*}{$\begin{array}{c}\text { Fine loamy; semectitic; Calcareaus; } \\
\text { Alkalinre; Hyper thermic; Aquollic } \\
\text { Salorthids }\end{array}$} & 22 & 239 & 47 & 35.0 & 7.9 & 85.3 & $\mathrm{SiC}$ & 425 & 453 & 122 & $0-18$ & Aw & \multirow{4}{*}{$\begin{array}{l}\text { Delmj } \\
\text { marsh } \\
\text { P5 }\end{array}$} \\
\hline & 31 & 208 & 60 & 38.0 & 8.0 & 78.6 & $\mathrm{Cl}$ & 386 & 275 & 339 & $18-28$ & Cw1 & \\
\hline & 23 & 263 & 57 & 32.0 & 8.1 & 72.3 & $\mathrm{Cl}$ & 379 & 240 & 381 & $28-43$ & Cw2 & \\
\hline & 35 & 231 & 26 & 21.0 & 8.1 & 60.0 & $\mathrm{~L}$ & 215 & 348 & 437 & $43-110$ & Cw3 & \\
\hline \multirow{4}{*}{$\begin{array}{c}\text { Clayey (fine); semectitic; Calcareaus; } \\
\text { Alkalinre; Hyper thermic; Typic } \\
\text { Chromoxerect }\end{array}$} & 12 & 360 & 17 & 41.5 & 7.7 & 0.7 & $\mathrm{C}$ & 580 & 340 & 80 & $0-25$ & $A_{k}$ & \multirow{4}{*}{$\begin{array}{c}\text { Sindi plain } \\
\text { P6 }\end{array}$} \\
\hline & 11 & 280 & 10 & 39.5 & 7.7 & 0.6 & $\mathrm{C}$ & 570 & 360 & 70 & $25-55$ & $\mathrm{~B}_{\mathrm{kw}}$ & \\
\hline & 21 & 263 & 11 & 38.1 & 7.8 & 0.7 & $\mathrm{C}$ & 580 & 350 & 70 & $55-100$ & $\mathrm{Cw} 2$ & \\
\hline & 25 & 154 & 8 & 31.7 & 7.7 & 0.5 & $\mathrm{C}$ & 500 & 370 & 130 & $100-120$ & Cw3 & \\
\hline \multirow{3}{*}{$\begin{array}{l}\text { Clayey (fine); semectitic; Calcareaus; } \\
\text { Alkalinre; Hyper thermic; Typic } \\
\text { Xerrochrepts }\end{array}$} & 11 & 225 & 19 & 35.4 & 8.0 & 14.2 & $\mathrm{C}$ & 560 & 320 & 120 & & $\mathrm{~A}$ & \\
\hline & 14 & 320 & 15 & 34.3 & 7.9 & 20.0 & $\mathrm{C}$ & 580 & 330 & 90 & $\begin{array}{r}0-25 \\
25-55\end{array}$ & $\mathrm{Bk}$ & Bashiqah \\
\hline & 13 & 244 & 3 & 33.0 & 8.1 & 7.6 & $\mathrm{C}$ & 566 & 350 & 84 & $\begin{array}{r}25-55 \\
55-105\end{array}$ & $\mathrm{C}$ & P7 \\
\hline Clavey (fine): semectitic: Calcareaus: & 15 & 245 & 29 & 31.4 & 8.1 & 32.4 & Sil & 189 & 700 & 101 & & Aw & \\
\hline Alkalinre. Hyner thermic. Tynic & 12 & 302 & 18 & 30.5 & 8.2 & 22.1 & $\mathrm{SiC}$ & 506 & 458 & 36 & $\begin{array}{r}0-30 \\
30-55\end{array}$ & $\mathrm{Bk}$ & Aqre \\
\hline $\begin{array}{l}\text { Alkalinre; Hyper thermic; Туріc } \\
\text { Calcixerects }\end{array}$ & 18 & 233 & 5 & 32.1 & 8.2 & 8.7 & $\mathrm{SiCl}$ & 378 & 600 & 22 & $\begin{array}{r}30-55 \\
55-110\end{array}$ & $\mathrm{C}$ & P8 \\
\hline
\end{tabular}




\section{Al-Bayati et al. / Basrah J. Agric. Sci., 34(2), 253-266, 2021}

The registered variation in the soil particles content is attributed mainly to the nature of the parent material and the nature of sedimentation prevailing at the region (Buringh, 1960). This variation in the particle content reflected on the prevailing texture in the study locations, the clayey texture (fine texture class) was recorded at Sindi and Bashiqah regions, while the loamy texture (moderate texture class) was observed at Rabia region.

The results of soil chemical properties, the values electrical conductivity were ranged between $0.5 \mathrm{dSm}^{-1}$ at $\mathrm{A}$ and $\mathrm{Cw} 3$ horizons for Sindi region, and $85.3 \mathrm{dSm}^{-1}$ at $\mathrm{Aw}$ horizon for Delmj marsh, with a tendency to rise in its value in the surface horizons and decline with depth, the reason was attributed to the rise of temperatures and evaporation in the study locations. The observed difference in the soil content of dissolved salts from location to another and horizon to another, because to the geomorphologic location conditions, dry climate and the decreased rainfall rates, all these reasons were reflected on soil salinity (Gracie et al., 1934).

The soil reaction values ranged between 7.5 and 8.2 which were identical to those indicated by Brady (1974) that the value of this property at arid and semi-arid areas ranges between 7 and 9. The higher values recorded in soils that have a high content of calcium carbonate, this is consistent with what was indicated by Dregne (1976).

Soil organic material content ranged between 1 and $60 \mathrm{gmKg}^{-1}$ soil, with a rising in the soil surface and gradually decline with depth at all studied locations. The low content of organic material in the soils is due to the prevailing climatic conditions of which are the high temperatures and lack of rainfall.

The soil content of calcium carbonate ranged between 12 and $360 \mathrm{gmKg}^{-1}$ soil at
Cy1 horizon in Rabia region and Ak horizon in Sindi region respectively. As observed from table (1) most selected locations for the study, except Rabia site have been characterized by high content of this component, which increased above 200 $\mathrm{gmKg}^{-1}$ soil, this result is consistent with what was mentioned by Buringh (1960). Benjamin \& Laliberte (2015) indicated extractable micronutrient concentrations .It was quite low overall and a little varied across Chronology.

The results also noted that there's almost a homogeneity in the distribution of calcium carbonate through the studied pedons, as the percent for this component did not change in the body of soil with depth, due to the fact that the source of carbonate in these soils is the erosion of the mechanically weathered sedimentary limestone rocks, and the transport of the results by the running water and their deposition in Mesopotamia basin. Soil content of the organic matter, calcium carbonate and gypsum effect in addition to soil content of clay fraction reflected on soil cat ions exchangeable capacity which ranged between 5.6 and $41.5 \mathrm{C} \mathrm{mol}(+) . \mathrm{Kg}^{-1}$ soil, the lower values were recorded in Rabia location, which indicates the importance of the mineralogical composition of clay fraction on this property.

\section{The total content of micronutrient in the studied soils}

Table (2) shows that there are significant differences in the weighted average of total manganese $(\mathrm{Mn})$ content in the soils, since the great soil group Typic Torrients (Pedon, 2) showed the least content reached 793.9 $\mathrm{mgKg}^{-1}$, while the great soil group Gypsiorthids (Pedon,3) showed the highest content is $1650.8 \mathrm{mgKg}^{-1}$, with the existence of fluctuation in its distribution in the soil body depending on the soil content of clay, this was confirmed by da Silva et al. (2019). 


\section{Al-Bayati et al. / Basrah J. Agric. Sci., 34(2), 253-266, 2021}

Table (2): Total micronutrient content distribution in the studied soils.

\begin{tabular}{|c|c|c|c|c|c|c|}
\hline \multirow[t]{2}{*}{$\begin{array}{l}\text { Samples No. at } \\
\text { every location }\end{array}$} & Total iron & Total copper & Total zinc & $\begin{array}{c}\text { Total } \\
\text { manganese }\end{array}$ & \multirow[t]{2}{*}{ Horizon } & \multirow[t]{2}{*}{$\begin{array}{l}\text { Location and } \\
\text { Pedon No. }\end{array}$} \\
\hline & $\%$ & & $\mathrm{mg} . \mathrm{Kg}^{-1}$ soil & & & \\
\hline \multirow{6}{*}{$\mathrm{n}=55$} & 2.41 & 23.5 & 56.0 & 1420 & $A_{p}$ & \multirow{5}{*}{$\begin{array}{c}\text { Abu Ghraib } \\
\text { P1 }\end{array}$} \\
\hline & 3.35 & 60.1 & 32.2 & 732 & $\mathrm{C}_{\mathrm{k} 1}$ & \\
\hline & 3.30 & 60.2 & 62.1 & 1443 & $\mathrm{C}_{\mathrm{k} 2}$ & \\
\hline & 2.85 & 51.5 & 71.0 & 1505 & $\mathrm{C}_{3}$ & \\
\hline & 2.41 & 50.0 & 66.0 & 1609 & $\mathrm{C}_{4}$ & \\
\hline & $2.86 \mathrm{~g}$ & $51.1 \mathrm{f}$ & $58.9 \mathrm{c}$ & $1373.1 \mathrm{~d}$ & $\begin{array}{r}\text { Weighted at } \\
\text { content }\end{array}$ & $\begin{array}{l}\text { e for element } \\
\text { e pedon }\end{array}$ \\
\hline \multirow{5}{*}{$\mathrm{n}=44$} & 3.21 & 70.3 & 35.0 & 756 & $A_{p}$ & \multirow{4}{*}{$\begin{array}{l}\text { Diyala } \\
\text { P2 }\end{array}$} \\
\hline & 3.30 & 71.0 & 34.5 & 746 & $\mathrm{C}_{\mathrm{k} 1}$ & \\
\hline & 3.35 & 72.0 & 30.2 & 655 & $\mathrm{C}_{\mathrm{k} 2}$ & \\
\hline & 4.31 & 73.4 & 31.5 & 850 & $\mathrm{C}_{3}$ & \\
\hline & $3.87 \mathrm{c}$ & $72.4 d$ & $32.2 \mathrm{f}$ & $793.9 \mathrm{~h}$ & $\begin{array}{r}\text { Weighted at } \\
\text { content }\end{array}$ & $\begin{array}{l}\text { e for element } \\
\text { e pedon }\end{array}$ \\
\hline \multirow{5}{*}{$\mathrm{n}=44$} & 2.52 & 23.3 & 74.5 & 1670 & $\mathrm{~A}$ & \multirow{4}{*}{$\begin{array}{l}\text { Rabia } \\
\text { P3 }\end{array}$} \\
\hline & 2.41 & 21.5 & 69.3 & 1640 & $\mathrm{~B}_{\mathrm{y}}$ & \\
\hline & 2.43 & 23.5 & 69.0 & 1650 & $\mathrm{C}_{\mathrm{y} 1}$ & \\
\hline & 2.53 & 25.6 & 66.6 & 1650 & $\mathrm{C}_{\mathrm{y} 2}$ & \\
\hline & $2.47 \mathrm{~h}$ & $23.7 \mathrm{~g}$ & $69.2 \mathrm{~d}$ & $1650.8 \mathrm{a}$ & $\begin{array}{r}\text { Weighted at } \\
\text { content }\end{array}$ & $\begin{array}{l}\text { e for element } \\
\text { e pedon }\end{array}$ \\
\hline \multirow{5}{*}{$\mathrm{n}=44$} & 2.81 & 26.5 & 56.7 & 1431 & $\mathrm{~A}$ & \multirow{4}{*}{$\begin{array}{l}\text { Ramadi } \\
\text { P4 }\end{array}$} \\
\hline & 3.35 & 25.1 & 35.5 & 750 & $\mathrm{~B}_{\mathrm{k}}$ & \\
\hline & 3.46 & 23.5 & 35.0 & 808 & $\mathrm{C}_{\mathrm{k} 1}$ & \\
\hline & 3.51 & 22.8 & 64.7 & 1339 & $\mathrm{C}_{\mathrm{k} 2}$ & \\
\hline & $3.32 \mathrm{e}$ & $24.2 \mathrm{~g}$ & $51.4 \mathrm{e}$ & $1129.5 \mathrm{~g}$ & $\begin{array}{r}\text { Weighted as } \\
\text { content }\end{array}$ & $\begin{array}{l}\text { e for element } \\
\text { e pedon }\end{array}$ \\
\hline \multirow{5}{*}{$\mathrm{n}=44$} & 4.20 & 78.0 & 66.3 & 1500 & $\mathrm{~A}_{\mathrm{w}}$ & \multirow{4}{*}{$\begin{array}{l}\text { Al-Delmj } \\
\text { marsh } \\
\text { P5 }\end{array}$} \\
\hline & 3.62 & 76.2 & 83.1 & 1620 & $\mathrm{C}_{\mathrm{w} 1}$ & \\
\hline & 3.60 & 75.3 & 65.0 & 1340 & $\mathrm{C}_{\mathrm{w} 2}$ & \\
\hline & 2.95 & 65.7 & 69.4 & 1518 & $\mathrm{C}_{\mathrm{w} 3}$ & \\
\hline & $3.30 \mathrm{f}$ & $70.0 \mathrm{e}$ & $69.5 \mathrm{a}$ & $1500.1 \mathrm{~b}$ & $\begin{array}{r}\text { Weighted a } \\
\text { content }\end{array}$ & $\begin{array}{l}\text { e for element } \\
\text { e pedon }\end{array}$ \\
\hline \multirow{5}{*}{$\mathrm{n}=44$} & 4.90 & 76.5 & 32.0 & 538 & $\mathrm{~A}_{\mathrm{k}}$ & \multirow{4}{*}{$\begin{array}{l}\text { Sindi } \\
\text { P6 }\end{array}$} \\
\hline & 4.83 & 75.7 & 50.0 & 1018 & $\mathrm{~B}_{\mathrm{kw}}$ & \\
\hline & 4.91 & 77.5 & 65.1 & 1340 & $\mathrm{C}_{\mathrm{w} 2}$ & \\
\hline & 4.21 & 69.5 & 76.4 & 1665 & $\mathrm{C}_{\mathrm{w} 3}$ & \\
\hline & $4.77 \mathrm{a}$ & $75.5 \mathrm{a}$ & $56.3 \mathrm{~d}$ & $1146.6 f$ & $\begin{array}{r}\text { Weighted as } \\
\text { content }\end{array}$ & $\begin{array}{l}\text { e for element } \\
\text { e pedon }\end{array}$ \\
\hline \multirow{4}{*}{$\mathrm{n}=33$} & 4.60 & 73.1 & 71.5 & 1600 & $\mathrm{~A}$ & \multirow{3}{*}{$\begin{array}{c}\text { Bashiqah } \\
\text { P7 } \\
\end{array}$} \\
\hline & 4.82 & 75.0 & 38.1 & 845 & $\mathrm{~B}_{\mathrm{k}}$ & \\
\hline & 4.63 & 72.5 & 62.1 & 1460 & $\mathrm{C}$ & \\
\hline & $4.68 \mathrm{~b}$ & $73.4 \mathrm{c}$ & $57.5 \mathrm{dc}$ & $1317.6 \mathrm{e}$ & $\begin{array}{r}\text { Weighted at } \\
\text { content }\end{array}$ & $\begin{array}{l}\text { e for element } \\
\text { e pedon }\end{array}$ \\
\hline \multirow{4}{*}{$\mathrm{n}=33$} & 2.62 & 70.5 & 62.0 & 1468 & $\mathrm{~A}_{\mathrm{w}}$ & \multirow{3}{*}{$\begin{array}{l}\text { Aqre } \\
\text { P8 }\end{array}$} \\
\hline & 4.12 & 76.0 & 43.6 & 970 & $B_{k}$ & \\
\hline & 3.61 & 75.3 & 68.0 & 1520 & $\mathrm{C}$ & \\
\hline & $3.46 \mathrm{~d}$ & $74.2 \mathrm{~b}$ & $60.8 \mathrm{~b}$ & $1380.8 \mathrm{c}$ & $\begin{array}{r}\text { Weighted as } \\
\text { content }\end{array}$ & $\begin{array}{l}\text { for element } \\
\text { e pedon }\end{array}$ \\
\hline
\end{tabular}


The recorded values for manganese element came compliant with what was indicated by Shukla et al. (2015), and the following liner equations show the distribution of this element content in the soil with depth at all studied pedions:

$$
\begin{gathered}
Y(P 1)=1116.7+2.47 X \\
Y(P 2)=690.65+0.94 X \\
Y(P 3)=1662.09+0.14 X \\
Y(P 4)=1069.31+0.15 X \\
Y(P 5)=1498.78-0.09 X \\
Y(P 6)=313.50+11.02 X \\
Y(P 7)=1320.49-0.32 X \\
Y(P 8)=1177.15+2.18 X
\end{gathered}
$$

The studied soils content from total zinc as observed from table (2) showed that the lowest content $32.2 \mathrm{mgKg}^{-1}$ has been recorded in the great soil group Gypsiorthids (Pedon, P3), due to the high soil content of gypsum and its negative impact on the soil microelement content, when he studied Gypsiferous soils in the western of Iraq, whereas the highest content has been recorded in the great soil group Typic Torrients (Pedon, P2) and Aquollic Salorthids (Pedon, P5) its reached 69.2 and $69.5 \mathrm{mg} . \mathrm{Kg}^{-1}$ respectively. The vertical distribution of the total content of this element shows the existence of a general trend to decline in its content with depth at some sites, while fluctuation in its distribution in other pedons, this distribution came compatible primarily with soil content of clay and organic matter secondarily. This result was consistent with what was observed by Kingsley et al. (2019), and the following liner equations indicate the total content distribution of this element in the studied soils with depth:

$$
Y(P 1)=43.30+0.19 X
$$

$$
\begin{gathered}
Y(P 2)=34.71-0.03 X \\
Y(P 3)=74.70-0.07 X \\
Y(P 4)=39.74+0.09 X \\
Y(P 5)=72.74-0.04 X \\
Y(P 6)=22.78+0.44 X \\
Y(P 7)=60.59-0.06 X \\
Y(P 8)=49.11+0.14 X
\end{gathered}
$$

Table (2) shows that the total copper content in the studied soils ranged between 21.5 and $78.0 \mathrm{mgKg}^{-1}$ at B horizon pedon P3 Rabia and A horizon for pedon P5 Delmj marsh respectively. The results indicate that there's a significant difference between studied Iraqi great soil groups, from a location to another. The weighted average for copper content reached $23.7 \mathrm{mgKg}^{-1}$ at Rabia P3, with no significant differences for Ramadi site P4 that reached $24.2 \mathrm{mg} \cdot \mathrm{Kg}^{-1}$, while Sindi site Typic Chromoxerect (P6) showed the highest content that reached $75.5 \mathrm{mg} \cdot \mathrm{Kg}^{-1}$, with a difference in the content of this element within the horizons of a single pedon due to the difference in the parent material for the studied soil of copper.

The obtained values about copper were compatible with what was observed by Liu $e t$ al. (2021) results showed that the physicochemical properties of the soils were significantly different, which led to differences in the nutritional quality of pepper fruits. The $\mathrm{pH}$ value had a significant effect on the absorption of trace elements in pepper, $\mathrm{Cu}$ concentrations were calculated by Iñigo et al. (2020) in references to 85.28 and $48.88 \mathrm{mg} / \mathrm{kg} \mathrm{Cu}$ and 83.69 and $72.05 \mathrm{mg} / \mathrm{kg}$ $\mathrm{Zn}$ at surface and at depth, respectively in soils in vineyards in La Rioja (Spain). While Jarallah \& Al-mayaly (2017) found a decrease in total copper concentration for all tested soil cakes are directly related to depth. 


\section{Al-Bayati et al. / Basrah J. Agric. Sci., 34(2), 253-266, 2021}

The total values of copper concentration are the highest in decreased surface layer and depth in some governorates of central Iraq. The distribution of the total copper with depth can be illustrated by the following liner equations:

$$
\begin{aligned}
& Y(P 1)=39.31+0.13 X \\
& Y(P 2)=70.01+0.03 X \\
& Y(P 3)=21.59+0.03 X \\
& Y(P 4)=27.12-0.03 X \\
& Y(P 5)=80.42-0.14 X \\
& Y(P 6)=78.55-0.05 X \\
& Y(P 7)=74.18-0.01 X \\
& Y(P 8)=70.81+0.05 X
\end{aligned}
$$

The soil content of total iron ranged between 2.41 and $4.91 \%$ with a significant difference in the distribution of the weighted averaged for this element, the lowest content was recorded at Pedon P3 reached 2.47\%, whereas the highest content was recorded at Pedon P6 site reached $4.77 \%$, with a clear correlation of this element content with the soil content of clay, these results were compatible with what was observed by Bhaskar et al. (2017). The following equations illustrate the total iron content distribution with depth in the studied soils:

$$
\begin{aligned}
& Y(P 1)=3.01+0.002 X \\
& Y(P 2)=2.76+0.014 X \\
& Y(P 3)=2.46+0.0002 X \\
& Y(P 4)=2.77+0.006 X \\
& Y(P 5)=3.88-0.012 X \\
& Y(P 6)=2.38-0.255 X \\
& Y(P 7)=4.69-0.0002 X \\
& Y(P 8)=2.87+0.009 X
\end{aligned}
$$

\section{The bioavailable content of micronutrients in the studied soils}

Table (3) shows that the available manganese content ranged between lowest content of $2.6 \mathrm{mgKg}^{-1}$ at Bk horizon for Ramadi pedon (Typic Calciorthids) and the highest content of $15.8 \mathrm{mgKg}^{-1}$ at $\mathrm{Cw} 1$ horizon in Delmj marsh pedon (Aquollic Salorthids), with significant differences in this element's weighted average content between selected pedons for the study.

The highest average for the weighted content was recorded at Delmj marsh pedon (Aquollic Salorthids), reached $15.10 \mathrm{mgKg}^{-1}$, while the lowest average of $3.84 \mathrm{mgKg}^{-1}$ was seen at Bashiqah pedon (Typic Xerrochrepts). The bioavailable manganese content average for the studied soils reached 6.5 $\mathrm{mg} \cdot \mathrm{Kg}^{-1}$, with a negative correlation between soil manganese content and soil clay content that reached $\mathrm{r}=-0.321$ as well as the soil content of calcium carbonate $r=-0.201$, while the correlation was showed high significantly positive with soil organic matter content $\mathrm{r}=0.912 * *$. Whereas the soil content of bioavailable zinc ranged between $0.30-1.60 \mathrm{mgKg}^{-1}$ at C3 horizon for Diyala pedon (Typic Torrients) and Cw1 horizon for Delmj marsh pedon (Aquollic Salorthids) respectively, with an average of soil content that reached $0.50 \mathrm{mgKg}^{-1}$ with a significant difference between the studied pedons, the highest weighted average was recorded at Delmj marsh pedon, while lowest value at Diyala pedon $0.34 \mathrm{mg} . \mathrm{Kg}^{-1}$, with a negative correlation with soil clay content that reached $r=-0.234$, and with the soil content of calcium carbonate $r=-0.394$, while the correlation of this element bioavailable was high significantly positive with the soil organic matter content that reached $\mathrm{r}=0.892 * *$.

Whereas the soils content of available copper ranged between $0.21 \mathrm{mg} . \mathrm{Kg}^{-1}$ for by horizon at Rabia region and $3.32 \mathrm{mgKg}^{-1}$ at Cw3 horizon for Al-Delmj marsh. With a significant differences in the weighted average between the studied pedons, AlDelmj marsh pedon (Aquollic Salorthids) excelled in this parameter in comparison with pedon Rabia (Typic Gypsiorthids), which showed a lower rate for available copper 


\section{Al-Bayati et al. / Basrah J. Agric. Sci., 34(2), 253-266, 2021}

weighted average. The study of soil's characteristics effect on this element availability has shown the existence of a negative correlation between the soil content of this element availability and the soil content of clay and calcium carbonate with values that reached $\mathrm{r}=-0.176$ and $\mathrm{r}=-0.235$ respectively while the correlation was highly significant with soil content of organic matter that reached $\mathrm{r}=0.978^{* *}$.

Table (3): The bioavailable micronutrient content distribution in the studied soils.

\begin{tabular}{|c|c|c|c|c|c|c|}
\hline \multirow{2}{*}{$\begin{array}{l}\text { Number of } \\
\text { samples }\end{array}$} & Iron & Copper & Zinc & Manganese & \multirow{2}{*}{ Horizon } & \multirow{2}{*}{ Location } \\
\hline & \multicolumn{4}{|c|}{$\mathrm{mgKg}^{-1}$ soil } & & \\
\hline \multirow{6}{*}{$\mathrm{n}=55$} & 4.5 & 0.27 & 0.49 & 10.5 & $A_{p}$ & \multirow{5}{*}{$\begin{array}{c}\text { Abu Ghraib } \\
\text { P1 }\end{array}$} \\
\hline & 4.2 & 0.42 & 0.38 & 4.0 & $\mathrm{C}_{\mathrm{k} 1}$ & \\
\hline & 4.0 & 0.45 & 0.39 & 9.3 & $\mathrm{C}_{\mathrm{k} 2}$ & \\
\hline & 3.8 & 0.33 & 0.42 & 9.0 & $\mathrm{C}_{3}$ & \\
\hline & 3.2 & 0.30 & 0.41 & 4.1 & $\mathrm{C}_{4}$ & \\
\hline & $3.83 \mathrm{e}$ & $0.36 \mathrm{ab}$ & $0.41 \mathrm{ab}$ & $6.95 \mathrm{f}$ & $\begin{array}{l}\text { Weighted } \\
\text { conter }\end{array}$ & $\begin{array}{l}\text { e for element } \\
\text { e pedon }\end{array}$ \\
\hline \multirow{5}{*}{$\mathrm{n}=44$} & 2.2 & 0.70 & 0.45 & 4.3 & $A_{p}$ & \multirow{4}{*}{$\begin{array}{l}\text { Diyala } \\
\text { P2 }\end{array}$} \\
\hline & 2.0 & 0.71 & 0.40 & 4.1 & $\mathrm{C}_{\mathrm{k} 1}$ & \\
\hline & 2.0 & 0.73 & 0.32 & 3.6 & $\mathrm{C}_{\mathrm{k} 2}$ & \\
\hline & 2.6 & 0.71 & 0.30 & 4.4 & $\mathrm{C}_{3}$ & \\
\hline & $2.37 \mathrm{a}$ & $0.71 \mathrm{c}$ & $0.34 \mathrm{a}$ & $4.23 b$ & $\begin{array}{l}\text { Weighted } \\
\text { conter }\end{array}$ & $\begin{array}{l}\text { e for element } \\
\text { e pedon }\end{array}$ \\
\hline \multirow{5}{*}{$\mathrm{n}=44$} & 3.2 & 0.35 & 0.65 & 5.5 & $\mathrm{~A}$ & \multirow{4}{*}{$\begin{array}{c}\text { Rabia } \\
\text { P3 }\end{array}$} \\
\hline & 3.0 & 0.21 & 0.53 & 5.4 & $\mathrm{~B}_{\mathrm{y}}$ & \\
\hline & 3.0 & 0.30 & 0.50 & 5.3 & $\mathrm{C}_{\mathrm{y} 1}$ & \\
\hline & 3.1 & 0.31 & 0.56 & 5.2 & $\mathrm{C}_{\mathrm{y} 2}$ & \\
\hline & $3.07 \mathrm{~b}$ & $0.29 \mathrm{a}$ & $0.55 b$ & $5.33 \mathrm{~d}$ & $\begin{array}{r}\text { Weighted } \\
\text { conter }\end{array}$ & $\begin{array}{l}\text { for element } \\
\text { e pedon }\end{array}$ \\
\hline \multirow{5}{*}{$\mathrm{n}=44$} & 2.1 & 0.70 & 0.50 & 4.0 & $\mathrm{~A}$ & \multirow{4}{*}{$\begin{array}{c}\text { Ramadi } \\
\text { P4 }\end{array}$} \\
\hline & 2.3 & 0.61 & 0.42 & 2.6 & $\mathrm{~B}_{\mathrm{k}}$ & \\
\hline & 2.5 & 0.45 & 0.41 & 3.4 & $\mathrm{C}_{\mathrm{k} 1}$ & \\
\hline & 2.5 & 0.32 & 0.44 & 5.0 & $\mathrm{C}_{\mathrm{k} 2}$ & \\
\hline & $2.37 \mathrm{a}$ & $0.49 b$ & $0.44 \mathrm{ab}$ & $3.95 \mathrm{a}$ & $\begin{array}{r}\text { Weighted } \\
\text { conte }\end{array}$ & $\begin{array}{l}\text { e for element } \\
\text { e pedon }\end{array}$ \\
\hline \multirow{5}{*}{$\mathrm{n}=44$} & 8.3 & 2.70 & 1.51 & 15.6 & $\mathrm{~A}_{\mathrm{W}}$ & \multirow{4}{*}{$\begin{array}{c}\text { Al-Delmj } \\
\text { marsh } \\
\text { P5 }\end{array}$} \\
\hline & 7.6 & 2.61 & 1.60 & 15.8 & $\mathrm{C}_{\mathrm{w} 1}$ & \\
\hline & 7.7 & 3.02 & 0.70 & 13.6 & $\mathrm{C}_{\mathrm{w} 2}$ & \\
\hline & 6.4 & 3.32 & 0.73 & 15.2 & $\mathrm{C}_{\mathrm{w} 3}$ & \\
\hline & $7.00 \mathrm{~g}$ & $3.10 \mathrm{e}$ & $0.93 c$ & $15.10 \mathrm{~g}$ & $\begin{array}{r}\text { Weighted } \\
\text { conter }\end{array}$ & $\begin{array}{l}\text { for element } \\
\text { e pedon }\end{array}$ \\
\hline \multirow{5}{*}{$\mathrm{n}=44$} & 4.5 & 1.50 & 0.55 & 5.2 & $\mathrm{~A}_{\mathrm{k}}$ & \multirow{4}{*}{$\begin{array}{l}\text { Sindi } \\
\text { P6 }\end{array}$} \\
\hline & 4.1 & 1.02 & 0.42 & 5.6 & $\mathrm{~B}_{\mathrm{kw}}$ & \\
\hline & 4.3 & 1.61 & 0.44 & 6.0 & $\mathrm{C}_{\mathrm{w} 2}$ & \\
\hline & 4.0 & 0.92 & 0.43 & 6.4 & $\mathrm{C}_{\mathrm{w} 3}$ & \\
\hline & $4.24 \mathrm{f}$ & $1.31 \mathrm{~d}$ & $0.46 \mathrm{ab}$ & $5.80 \mathrm{e}$ & $\begin{array}{r}\text { Weighted } \\
\text { conter }\end{array}$ & $\begin{array}{l}\text { e for element } \\
\text { e pedon }\end{array}$ \\
\hline \multirow{4}{*}{$n=33$} & 3.8 & 1.10 & 0.73 & 4.2 & $\mathrm{~A}$ & \multirow{3}{*}{$\begin{array}{c}\text { Bashiqah } \\
\text { P7 }\end{array}$} \\
\hline & 3.5 & 0.83 & 0.51 & 3.6 & $\mathrm{~B}_{\mathrm{k}}$ & \\
\hline & 3.6 & 0.68 & 0.46 & 3.8 & $\mathrm{C}$ & \\
\hline & $3.62 \mathrm{~d}$ & $0.82 \mathrm{c}$ & $0.54 \mathrm{ab}$ & $3.84 \mathrm{a}$ & $\begin{array}{r}\text { Weighted } \\
\text { conter } \\
\end{array}$ & $\begin{array}{l}\text { e for element } \\
\text { e pedon }\end{array}$ \\
\hline \multirow{4}{*}{$n=33$} & 2.6 & 1.60 & 0.61 & 5.8 & $\mathrm{~A}_{\mathrm{w}}$ & \multirow{3}{*}{$\begin{array}{c}\text { Aqre } \\
\text { P8 }\end{array}$} \\
\hline & 3.7 & 1.42 & 0.43 & 5.0 & $\mathrm{~B}_{\mathrm{k}}$ & \\
\hline & 3.4 & 1.30 & 0.40 & 4.8 & C & \\
\hline & $3.25 \mathrm{c}$ & $1.40 \mathrm{~d}$ & $0.46 \mathrm{ab}$ & $5.12 \mathrm{c}$ & $\begin{array}{l}\text { Weighted } \\
\text { conter }\end{array}$ & $\begin{array}{l}\text { e for element } \\
\text { e pedon }\end{array}$ \\
\hline
\end{tabular}




\section{Al-Bayati et al. / Basrah J. Agric. Sci., 34(2), 253-266, 2021}

The study of the distribution of soil content of available iron has shown that its ranged between $2.0-8.3 \mathrm{mg} . \mathrm{Kg}^{-1}$, with significant differences in the weighted average of this element available content that reached 2.37 $\mathrm{mg} \cdot \mathrm{Kg}^{-1}$ for Diyala and Ramadi pedons and 7.0 mg. $\mathrm{Kg}^{-1}$ at Al-Delmj marsh pedon with an average of $3.8 \mathrm{mg} \cdot \mathrm{Kg}^{-1}$, the obtained values were compatible with the results of Donald $e t$ al. (1952) and Shukla et al. (2020).

The study of the effect of soil properties on iron availability showed a negative correlation with soil content of clay and calcium carbonate with values that reached $\mathrm{r}=-0.145$ and $r=-0.185$ respectively, while the correlation was significantly positive with soil organic matter content $\mathrm{r}=0.901^{* *}$, and to identify the soil bioavailable content of these elements natural distribution,

They were arranged according to their supremacy in the studied soil samples as follows; $\mathrm{Mn}>\mathrm{Fe}>\mathrm{Cu}>\mathrm{Zn}$ in most of the studied pedons except pedon P1 and P3 the supremacy showed the following formula: $\mathrm{Mn}>\mathrm{Fe}>\mathrm{Zn}>\mathrm{Cu}$ as shown in table (4). The results indicate that the difference in the studied great soil groups properties has a clear impact on the soil content of micronutrients, as soils showed variations in the physical and chemical properties which was reflected on its content of micronutrients, the highest content was recorded at sub great soil group (Aquollic Salorthids), while the sub great group (Typic Xerrochrepts) showed lower content of bioavailable Manganese, while the lowest value of available Zinc content was recorded at sub great soil group (Typic Torrients), and the lowest bioavailable copper content was recorded at sub great group (Typic Gypsiorthids), while the lowest bioavailable Iron content was recorded at sub great soil groups(Typic Torrients and Typic Chromoxerect ), which clearly shows the different weathering processes impact on that affected on the differences of the soil physical, chemical and mineralogical properties which resulted variation in the soil content of available Iron, Manganese, Zinc and Copper (da Silva et al., 2019).

To assess the studied soils fertility status in terms of its studied available micro nutrients content, the results in Tab. 4 shows that $77 \%$ of the studied soils suffer from Zinc deficiency, while $65 \%$ of the samples were below the critical limit for Iron element, while not no samples below critical limits for Manganese and Copper were registered, we conclude from this that the fertility status of the soils under study which gives an indicator for the fertility status of the Iraqi soils suffer from a lack of micronutrients and the soil management practices at these conditions need to raise its contents either by agricultural rotation or plant residue turn or the addition of acidity react conditioners and organic matters (Al-Bayati, 1993).

Table (4): The minimum and maximum level of soil available content for some micronutrients and their fertility evaluation.

\begin{tabular}{ccccc}
\hline $\begin{array}{c}\text { The percent of samples below } \\
\text { the critical limit }\end{array}$ & $\begin{array}{c}\text { The critical limit of the } \\
\text { elements } \mathrm{Mg}_{\mathrm{Kg}} \mathrm{K}^{-1 *}\end{array}$ & $\begin{array}{c}\text { Average } \\
\mathrm{Mg} \cdot \mathrm{Kg}^{-1}\end{array}$ & $\begin{array}{c}\text { Range } \\
\mathrm{Mg} \cdot \mathrm{Kg}^{-1}\end{array}$ & The element \\
\hline 0 & 0.25 & 6.29 & $15.8-2.6$ & Manganese \\
\hline 77 & 0.60 & 0.52 & $1.6-0.3$ & Zinc \\
\hline 0 & 0.20 & 0.89 & $3.32-0.21$ & Copper \\
\hline 65 & 4.00 & 3.72 & $8.3-2.0$ & Iron \\
\hline
\end{tabular}




\section{Al-Bayati et al. / Basrah J. Agric. Sci., 34(2), 253-266, 2021}

\section{Conclusions}

1- There is a difference in the total and bioavailable content of micronutrients with different soil order.

2- There is a significant difference in the total and bioavailable content of these elements with the variances in the chemical and physical properties of the soil.

3- It was observed that most of the soil orders under study had a content less than the critical limit for iron and zinc, which indicates the response of the plants grown in them to adding iron and zinc in the form of fertilizers in these soils.

4-The pedogenic distribution showed a general trend of decreasing the forms of studied micronutrients with depth.

\section{Acknowledgements}

We would like to thank Prof. Dr. Muhammad A. Jamal, College of Agriculture, University of Mosul, and Saadi K. Muhammad Ali, Ministry of Higher Education and Scientific Research for their support and contributions during the fieldwork and for their efforts in conducting, some analyzes on the laboratory side.

\section{References}

Al-Agidi, W. K. (1986). Pedology- soil survey and classification. The Ministry of Higher Education and Scientific Research. University of Baghdad, 286pp. (In Arabic).

Al-Bayati, A. H. I. (1993). The effect of some soil management practices in the growth and yield of maize. Ph. D. Thesis. College of Agriculture. University of Baghdad, 180p. (In Arabic).

Amos, E. M., Robert, M., \& Fergus, S., (2016). Variability of soil micronutrients concentration along the slopes of Mount Kilimanjaro, Tanzania. Applied and Environmental soil Science, 2016 Article ID 9814316. https://www.hindawi.com/journals/aess/2016/9814 316/
Benjamin, L. T., \& Laliberte, E. (2015). Soil development and nutrient availability along a 2 million-year coastal dune chronosequence under species-rich Mediterranean Shrubland in Southwestern Australia. Ecosystems, 18, 287-309. https://doi.org/10.1007/s10021-014-9830-0

Bhaskar, B. P., Tiwari, G., \& Prasad, J. (2017). Pedogenic influence on profile distribution of total and DTPA-extractable micronutrients in rice growing hydric soils of Majuli river island, Assam, India. Spanish Journal of Soil Science, 7, 59-85. https://doi.org/10.3232/SJSS.2017.V7.N1.05

Brady, N. C., (1974). The nature and properties of soils. 8th edition. 1071pp.

https://www.amazon.com/Nature-Properties-Soils8th/dp/B0006D800S .

Chahal, D. S., Sharma B. D., \& Singh, P. K. (2014). Distribution of forms of Zinc and their association with soil properties and uptake in different soil orders in semi-arid soils of Punjab, India. Communications in Soil Science and Plant Analysis. Taylor \& Francis Publisher. London W1T3JH. 2873pp. https://doi.org/10.1080/00103620500306031

Chandragouda, G., Rudramurthy, H. V., \& Rajesh, N. L. (2017). Fertility status of soil along the water course of selected distributory-14 of Shahapur branch canal of UKP command area in Yadgir district of Karnataka. Asian Journal of Soil Science, 12(1), 108-115.

https://doi.org/10.15740/HAS/AJSS/12.1/108-115

da Silva, R. C. F., da Silva, F. B. V., Biondi, C. M. , do Nascimento C. W. A., \& de Oliveira, E. C. A. (2019). Assessing the content of micronutrients in soils and sugarcane in different pedogeological contexts of northeastern Brazil. Rev Bras Cienc Solo: 43:e0180228. Division-Soil Use and Management. Commission-Soil Fertility and Plant Nutrition.

https://www.scielo.br/j/rbcs/a/78CkX4VrFqFnPz MGDhqzw3P/?lang=en .

Day, P. R. (1965). Particle Fractionation and ParticleSize Analysis. In C. A. Black D. D. Evans J. L. White L. E. Ensminger \& F. E. Clark, et al. (Eds.), Methods of Soil Analysis (pp. 545-567). John Wiley \& Sons, Ltd. https://doi.org/10.2134/agronmonogr9.1.c43 


\section{Al-Bayati et al. / Basrah J. Agric. Sci., 34(2), 253-266, 2021}

Donald, C., Passey, B., \& Swaby, R. ( 1952 ). Bioassay of available trace metals from Australian Soils. Australian Journal of Agriculture. Research. 3, 305325. https://doi.org/10.1071/AR9520305

Donisa, C., Mocanu, R., \& Steinnes, E. (2003). Distribution of some major and minor elements between fulvic and humic acid fractions in natural Soils. Geoderma, 111(1-2), 75-84. https://doi.org/10.1016/S0016-7061(02)00254-9

Dregne, H. E. (1976). Soils of arid regions. Elsevier Scientific Pub. Co.

Hesse, P. R. (1971). A textbook of soil chemical analysis. London: J. Murray.

Iñigo, V., Marín, A., Andrades, M., Jiménez-Ballesta, R., Iñigo, V., Marín, A., Andrades, M., \& JiménezBallesta, R. (2020). Evaluation of the copper and zinc contents of soils in the vineyards of La Rioja (Spain). Environments - MDPI, 7(8), 1-10. https://doi.org/10.3390/environments7080055

Jackson, M. L., (1958). Soil Chemical analysis. Englewood cliffs, New Jersey. ED. Prentie-Hall. Inc., pp:854. https://doi.org/10.1002/jpln.19590850311

Jarallah, R. S., \& Al-mayaly, B. H. F. (2017). Effects of rivers slop and soil depth on total copper concentration in some of central provinces of Iraq. Journal of Agriculture and Veterinary Science, 10(12), 57-62. https://doi.org/10.9790/23801012025762

Kingsley, J., O, A. E., Akpan-Idiok, A. U., \& Effiom, O. D. (2019). Status and distribution of soil available micronutrients along a hillslope at Ekpri Ibami in Akamkpa Local Government Area of Cross River State, Nigeria. African Journal of Agricultural Research, 14(1), 40-45. https://doi.org/10.5897/AJAR2016.13634

Lindsay, W. L., \& Norvell, W. A. (1978). Development of a DTPA soil test for zinc, iron, manganese and copper. Soil Science Society America Journal, 42, (3) 421-428. https://doi.org/10.2136/sssaj1978.0361599500420 0030009x

Liu, Z., Huang, Y., Tan, F., Chen, W., \& Ou, L. (2021). Effects of soil type on trace element absorption and fruit quality of pepper. Frontiers in Plant Science, 12, $698796 . \quad$ https://doi.org/: 10.3389/fpls.2021.698796

Page, A. L., Millr, R. H., \& Keeney, D. R. (1982). Methods of soil analysis part (2). Agronomy . 9.pp:1159.

https://acsess.onlinelibrary.wiley.com/doi/book/10 .2134/agronmonogr9.2.2ed

Pegoraro, R. F., Silva, I. R., Novais, R. F., Mendonça, E. S., Gebrim, F. O., \& Moreira, F. F. (2006). Diffusive flux and bioavailability of micronutrients in soils: Influence of liming, soil texture and green manure. Revista Brasileira de Ciência do Solo 30(5):859-868 https://doi.org/10.1590/S010006832006000500012

Richards, L. A. (Ed.). (1954). Diagnosis and improvement of saline and alkali soils. USDA.HB. No.60.pp:154

Ross, M. W., Allaway, W. H., House, W. A., \& Kubota, J., (1991). Geographic Distribution of Trace Element Problems. Book Series: SSSA Book Series. 991. https://doi.org/10.2136/sssabookser4.2ed.c2

Sharma, B. D., Rajinder, A. S., Saini, S., \& Dhaliwal, S. S. (2011). Distribution of different forms of $\mathrm{Mn}$ and their association with soil properties in arid zone soils of Punjab, India. Archives of Agronomy and Soil Science, 57, 15-26. https://doi.org/10.1080/03650340903222310

Shukla, A. K., Behera, S. K., Singh, V. K., Prakash, C., Sachan, A. K., \& Dhaliwal, S. S. (2020). Premonsoon spatial distribution of available micronutrients and sulphur in surface soils and their management zones in Indian Indo-Gangetic Plain. PLoS ONE, 15, e0234053. https://doi.org/10.1371/journal.pone.0234053

Shukla, A. K., Malik, R. S., Tiwari, P. K., Prakash, C., Behera, S. K., Yadav, H., \& Narwal, R. P. (2015). Status of micronutrient deficiencies in soils of haryana impact on crop productivity and human health. Indian Journal of Fertilisers,. 11, 16-27.

Soil Survey Division Staff (2017). Soil survey manual. Pp: 84-139. In Ditzler, C., Scheffe, K. \& Monger, H. C. (Eds.). USDA Handbook 18. Government Printing Office, Washington, D. C. 603pp. https://www.nrcs.usda.gov/wps/portal/nrcs/detailf ull/soils/ref/?cid=nrcs142p2_054262

Soil Survey Staff (2006). Key to Soil taxonomy. 10th edition.

Tucker, T. C., \& Kurts, E. (1955). A comparison of several chemical methods with the bioassay procedure for extracting Zinc from soils. Soil Science. American . Proceeding . 19, 477-481. 


\title{
التوزيع البيدوجيني لبعض المغذيات الصغرى في تحت مجاميع الترب العظمى السائدة في العراق
}

\author{
علي حسين ابراهيم البياتي و عبدالكريم احمد مخيلف العلواني2 ومحمد عبدالمنعم حسن 1 \\ 1قسم علوم التربة و الموارد المائية، كلية الزر اعتجامعة الانبار \\ 2مركز در اسات الصحر اء، جامعة الانبار الصنار
}

المستخلص: شملت الدراسة تحليل (341) نموذج تمثل (8) بدونات غطت مجاميع الترب العظمى السائدة في العراق وهي: Aquollic Salorthids, Typic Calciorthids, Typic Gypsiorthids, Typic Torrients, Typic Torrifluvents, و Typic Xerrochrepts و Typic Chromoxerects,

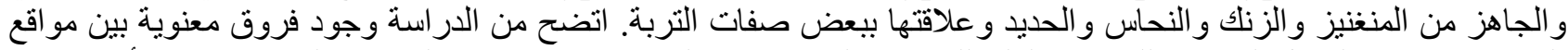

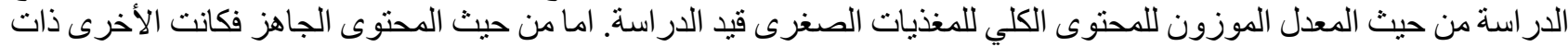

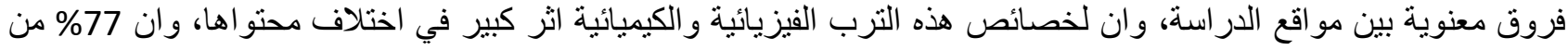

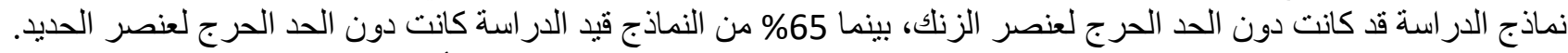

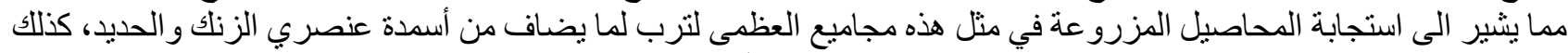

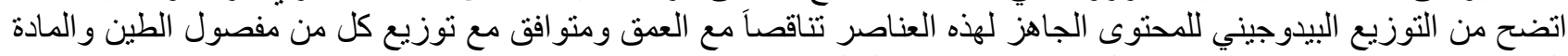

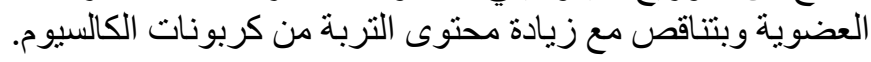
الكلمات المفتاحية: المغذيات الصغرى، ترب العراق، صفات التربة. 